\title{
Effects of Black Garlic Supplementation and Exercise on TBARS, HSP 70 and cOX-2 Expression after High-intensity Exercise
}

\author{
Yeong-Ho Baek', Sang-Ho Lee', Min Ho Han², Yung-Hyun Choi, ${ }^{2,3}$, Seung-Hyun Kim and Yi Sub Kwak * \\ ${ }^{1}$ Department of Physical Education, Pusan National University, Busan 609-735, Korea \\ ${ }^{2}$ Department of Biomaterial Control, Graduate School, Dong-Eui University, Busan 614714, Korea \\ ${ }^{3}$ Department of Biochemistry and Research Institute of Oriental Medicine, Dong-Eui University College of Oriental Medicine, Busan 614-052, \\ Korea \\ ${ }^{4}$ Department of Physical Ecucation, Dong-Eui University, Busan 614-714, Korea
}

Received March 13, 2012 /Revised April 28, 2012 /Accepted May 7, 2012

\begin{abstract}
The purpose of this study was to investigate the effects of black garlic supplementation and exercise on TBARS, HSP 70, and COX-2 expression after high-intensity exercise in rats. Twenty-four male Sprague-Dawley rats (4 weeks) were used in this study. Experimental groups were a control group $(A, n=6)$, black garlic supplementation group $(B, n=6)$, exercise group $(C, n=6)$, and black garlic supplementation with exercise group $(\mathrm{D}, \mathrm{n}=6)$. High-intensity exercise was performed by treadmill running (every $10 \mathrm{~min}$ speed increased gradually; 15 24 m/min, $0^{\circ}$ grade) and $2.86 \mathrm{~g} / \mathrm{kg}$ black garlic for 4 weeks. The findings of this study were as follows: TBARS levels were significantly lower in the D group compared to the other group and B and C groups were significantly lower in TBARS levels than in the A group. HSP 70 expression was lower in the B group compared to the other groups. COX-2 expression has showed a similar expression in all groups. Therefore, it is considered that black garlic intake and exercise may reduce oxidative stress.
\end{abstract}

Key words : Black garlic, TBARS, HSP 70, COX-2

\section{서 론}

규칙적인 신체활동은 신진대사를 원활하게 하고 비만, 동맥 경화, 고혈압, 당뇨병 등의 생활습관 병을 예방하고 치료하는 데 도움이 된다. 그러나 자신의 능력을 능가하는 과도한 신체 적 활동은 골격근과 심근에서 ischemia-reperfusion 상태를 초 래하여 생체 내에 활성산소종, 산화스트레스, 지질과산화물을 증가시켜 인체에 부정적인 영향을 미치게 된다[13,41]. 또한 세포가 외부, 또는 내부로부터 스트레스를 받을 경우 세포 내 단백질의 unfolding이 일어나며 hydrophobic한 부분이 수용 액에 노출되고 단백질 aggregation이 일어난다. 이때 HSPs (Heat shock proteins)들은 unfolding된 단백질과 결합하여 refolding을 유도하고 단백질을 유지시킨다[39,42].

HSP에 영향을 주는 요인으로는 환경적 스트레스, 병리적 스트레스, 중금속에 대한 노출, 혈액 및 조직의 삼투압의 변화, 체온의 변화, 산화적 스트레스의 증가, 노화 등이 있으며 이 외에도 다양한 스트레스에 대항하여 발현이 증가한다 [28,30,38]. 이 중 HSP 70은 세포질에 존재하여 운동이나 트레 이닝을 하는 동안 나타나는 다양한 스트레스에 의해 발현되어 손상된 단백질의 안정적인 3 차 구조의 형성을 통해 골격근 내 단백질의 변성을 예방할 뿐만 아니라 새로운 단백질의 생

\footnotetext{
*Corresponding author

Tel : +82-51-890-1546, Fax : +82-51-890-2643

E-mail : ysk2003@deu.ac.kr
}

성 과정에서도 관여하는 molecular chaperon 기능을 하는 것 으로 보고되고 있다[11,15].

선행연구에서 운동 환경온도가 증가함에 따라 small HSP인 aB-crystallin의 발현량이 증가를 보였는데, 이러한 현상은 체 온과 운동 환경의 상승으로 인한 화학적 변성 과정의 촉진으 로 aB-crystallin의 활성화의 증가를 제시하고 있고[5,33], 지속 시간에 따른 운동과 탈진적 운동을 시킨 결과 골격근에서 운 동과 열 환경에 의해서 산화적 스트레스를 증가시켜 stress proteins의 합성을 향상시킨다고 하였다[25].

$\mathrm{COX}$ (cyclooxygenase)는 COX-1과 COX-2의 두 가지 이성 체가 존재하는데[40], COX-1은 혈관, 위, 신장의 정상조직에서 발견되며, 혈류의 유지나 점액과 중 탄산염의 생성, 신장 기능 조절과 같은 신체의 항상성 유지에 관여하는 반면 COX-2는 염증 반응뿐만 아니라 혈액응고, 신장기능, 혈관조절 및 면역 반응 등에 관여하고, 염증성 cytokine이 분비되면 COX-2가 활성화 된다[34]. 또한 COX-2는 염증조직, 악성 종양조직에서 정상세포에 비해 많은 양의 프로스타글라딘의 생성을 유도하 여 혈관 생성을 촉진하고 세포의 증식을 도울 뿐 아니라 면역 능력을 억제함으로써 암세포 성장에 좋은 환경을 제공하여 $\mathrm{COX}-2$ 의 발현은 또 다른 질병의 병원성과 직접적인 연관성을 시사하고 있다[12].

마늘은 백합과 파 속에 속하는 식물로서 식품의 맛과 건강 을 증진시키는 대표적인 식품 중의 하나로 우리나라 전통 식 생활에서 필수적인 향신료로 사용되고 있으며[27], 마늘의 성 
분 중 생체 기능을 조절하는 allicin은 콜레스테롤 저하 및 노화 방지 작용 등 건강 유지에 유익한 식품으로 알려있다[35]. 또한 마늘을 고온 항온기에 일정기간 숙성시킬 경우 마늘성분과 효소 등에 의해 마늘 인편이 내부까지 모두 흑색으로 변화 하는데, 이를 흑마늘이라고 지칭하며[2], 흑마늘의 제조공정 중 색소의 변화는 마늘 자체성분의 갈변반응에 의해서 일어나 고, 이러한 반응으로 인하여 polyphenol 및 flavonoids 함량의 증가, total pyruvate 및 thiosulfinate의 증가, galactose, glucose, fructose 함량의 증가, 구성아미노산 중 glutamic acid 함량과 proline과 aspartic acid의 증가 등이 나타난다[37]. 이 러한 변화는 피로회복, 신경통, 갱년기 장애, 무력감 극복, 소 화와 흡수를 촉진 시키고, 항 산화 및 항암효과가 있으며, 신진 대사 촉진과 세포강화, 해독작용 등의 효능을 가지고 있다[3].

규칙적인 운동은 성인병을 예방하고 건강한 삶을 유지하여 삶의 질을 향상시킬 수 있으며, 유산소성 운동은 염증반응으 로 인한 심혈관계 질환과 면역기능 약화를 예방할 수 있다. 그러나 너무 높은 강도로 운동을 수행하면 산소 소비를 증가 시켜 운동 시 근육의 활성산소종 생성을 증가시켜 불포화지방 산과 반응하여 지질과산화가 발생하는데 이 과정에서 생성된 과산화라티칼이 산화적 손상의 원인이 된다[22]. 또한 면역 매개체 및 효소방출을 증가시켜 모세혈관뿐만 아니라 내피세 포에서도 구조적 손상이 일어난다.

이상과 같이 고강도의 탈진적 운동으로 인해 스트레스가 증가하여 TBARS, HSP 및 $\mathrm{COX}$ 의 발현이 높아 질 가능성이 높으나 규칙적인 운동과 흑마늘의 투여로 스트레스를 완화시 켜 줄 것으로 기대하며, 대부분의 선행연구가 운동과 관련하 여 TBARS 농도와 HSP 및 COX의 발현을 연구하였으나, 운동 영양학적 관점에서 선행연구는 미비한 실정이다. 따라서 본 연구는 흰쥐를 대상으로 흑마늘 투여와 운동을 시켜 고강도 운동을 실시하였을 때 TBARS, HSP 70 및 COX-2의 발현에 어떠한 영향을 미치는지 구명하는데 목적이 있다.

\section{재료 및 방법}

\section{실험동물}

생후 4 주령 Sprague Dawley계 수컷 흰쥐 24마리(Samtako, Korea)를 구입하여 1 주일간 일반사료로 적응시켰다. 그룹은 흑마늘운동군(6마리), 운동군(6마리), 흑마늘군(6마리), 대조군 (6마리)으로 사육은 cage $50 \times 30 \times 25.5 \mathrm{~cm}$ 의 크기에 2마리씩 사 육하였으며, 사육실의 온도는 $22.0 \pm 1.0^{\circ} \mathrm{C}$, 상대습도는 $50 \pm 10 \%$ 로 조절하고, 명암주기는 12 시간 간격으로 유지하였다. 실험 동물의 신체적 특성은 Table 1과 같다.

\section{식이조성 및 훈련방법}

사료는 $\mathrm{F}$ 사의 정제된 일반사료를 사용하여 모든군에게 섭 취하도록 했으며, 물은 충분히 섭취하도록 공급하였다. 흑마
Table 1. Physical characteristics of experimental rats

\begin{tabular}{cccc}
\hline Group & Number & Aged (wk) & Body weight $(\mathrm{g})$ \\
\hline A & 6 & 5 & $172.5 \pm 4.81$ \\
B & 6 & 5 & $175.1 \pm 4.57$ \\
C & 6 & 5 & $174.0 \pm 4.63$ \\
D & 6 & 5 & $175.3 \pm 3.83$ \\
\hline
\end{tabular}

Values are $\mathrm{M} \pm \mathrm{SD}$.

A: normal group

B: exercise group

C: black garlic intake group

D: black garlic intake with exercise group

늘섭취는 유산소운동과 흑마늘군을 대상으로 주 5회 운동 30 분 전에 C사의 흑마늘진액 $2.86 \mathrm{~g} / \mathrm{kg}$ 의 정량을 구강 투여 시켰 으며[29], 체중을 측정하여 증가한 체중에 비례하여 흑마늘 투 여량을 늘려갔다. 구강투여 시 받는 스트레스를 동일하게 하 기 위하여 운동군과 대조군은 물을 구강투여 시켰다.

실험동물의 운동은 트레드밀(Pro-Jog EJ36GLE, Korea Hi-Tech)로 실시하였으며, 운동은 1주차에 속도 $15 \mathrm{~m} / \mathrm{min}$ $(0 \%$ grade), 주 5 회, 1 일 30 분 실시하였고, 2 주에서 4 주차에는 속도 $15 \mathrm{~m} / \mathrm{min}$ ( $0 \%$ grade), 주5회, 1 일 60 분으로 실시하였다. 고강도 운동은 시료를 채취하기 바로 직전에 실시하였으며, 일회성 고강도 운동으로 $15 \mathrm{~m} / \mathrm{min}$ 속도로 시작하여 10 분마다 점진적으로 속도를 높여 $24 \mathrm{~m} / \mathrm{min}$ 속도까지 높였고, 더 이상 쥐들이 외부 자극에도 운동을 하지 않고, 지속할 수 없다고 판단되었을 때 운동을 중지하였다[4,14].

\section{시료수집 및 분석방법}

각 실험 군의 실험동물은 희생하기 전 12 시간 이상 절식시 켜 ether 마취 후 복부를 절개하여 혈액과 간을 채취하였다. 채취 후 액체 질소에 급속 동결시킨 후 $-70^{\circ} \mathrm{C}$ 에 보관하여 TBARS, HSP 70과 COX-2을 분석하였다.

지질과산화를 측정하는 방법으로 과산화지표인 Thiobarbituric acid reactive substance (TBARS)는 ZeptoMetrix의 Assay Kit 를 이용하여 Ohkawa 등[28]이 기술한 방법을 이용하여 Thiobarbituric acid (TBA)와 반응하는 물질을 추출하여 측정 하였다. 혈장 $0.2 \mathrm{ml}$ 에 $8.1 \%$ sodiumdodecyl sulfate와 $20 \%$ acetic acid $1.5 \mathrm{ml}$ 를 가한 후 잘 섞고. $0.8 \% \mathrm{TBA} 1.5 \mathrm{ml}$ 와 증류 수 $0.6 \mathrm{ml}$ 를 넣고 $95^{\circ} \mathrm{C}$ 에서 1 시간 가열 후 5 분간 냉각하였고, 증류수 $1 \mathrm{ml}$ 와 $\mathrm{n}$-butanol/pyridine $(15: 1, \mathrm{v} / \mathrm{v})$ 과 $5.0 \mathrm{ml}$ 의 증 류수를 가하여 30 초간 진탕하였다. $3,000 \mathrm{rpm}$ 에서 15 분간 원 심 분리한 후 상층액을 취하여 10 분간 실온에서 안정시킨 후 $532 \mathrm{~nm}$ 에서 흡광도를 측정하였다.

실험 동물에서 적출한 조직을 $\mathrm{PBS}$ 용액을 이용하여 조직 내 의 혈액을 최대한 제거한 후 해부가위를 이용하여 세절하였 다. 다음으로 단백질을 추출하기 위해 lysis buffer (Loche. CA) 에 protease inhibitor (Loche. CA)가 함유된 용액을 첨가하여, 
호모게나이저에 마쇄하여 $4^{\circ} \mathrm{C}$ 에 $30 \mathrm{~min}$ 간 lysis후, $4^{\circ} \mathrm{C} 14,000$ $\mathrm{rpm}$ 에서 $30 \mathrm{~min}$ 동안 원심분리 하였다. 원심 분리된 용액 중 상층액 만을 분리한 후 상층액의 $2 \mu \mathrm{l}$ 를 protein assay 용액 (Bio-Rad, USA) $1 \mathrm{ml}$ 에 첨가한 다음 spectrophotometer (eppendorf, USA)를 이용하여 $560 \mathrm{~nm}$ 의 흡광도에서 단백질 량을 정량하였다. 정량화 된 단백질에서 각 샘플 당 동일한 단백질량 $(20 \mu \mathrm{g})$ 을 SDS-gel loading 용액에 총 $20 \mu \mathrm{l}$ 가 되도록 혼합한 다음 $100^{\circ} \mathrm{C}$ 에서 10 분간 변성시켰다. 변성된 단백질(20 ul)을 스탠다드 단백질 마커(SDS-PAGE molecular weight maker, Bio-rad)와 함께 Mini-Protein II dual-slab apparatus(Bio-Rad)에 의해 만들어진 10\% SDS-polyacrylamide gels 에 각 샘플을 주입 한 다음 $100 \mathrm{~V}$ 에서 2시간 동안 단백질이 바닥에 닿을 때까지 전기영동 하였다. 전기 영동된 단백질을 PVDF membrane (Amersham, USA)에 전이하기 위해 Mini trans - module (Bio-Rad)를 이용하여 transfer 용액 $(190 \mathrm{mM}$ glycine, $50 \mathrm{mM}$ Tris-base, 20\% methanol, 0,05\% SDS)속에 단백질이 전기영동된 젤과 PVDF membrane (millipore) 및 $3 \mathrm{M}$ paper를 차례로 겹치도록 한 다음 $240 \mathrm{~mA}$ 에서 2 시간 동안 전이 하였다. 단백질이 전이된 membrane은 phosphate-buffered saline (PBS) (Nacl 8g, KCl 0.2 g, Na2HPO4 1.44 g, $\mathrm{KH} 2 \mathrm{PO} 40.24 \mathrm{~g}, \mathrm{pH} 7.4$ )에 $5 \%$ skim milk가 첨가된 용액에서 1시간 동안 rocker platform (Fine PCR, Co)에서 blocking되었 다. 그 다음 membrane는 PBS에 $0.1 \%$ tween-20이 함유된 용액 (PBST)에서 10분간 3번 세척되었으며, 세척된 membrane은 일차 항체인 Monoclonal COX-2 antibody, Monoclonal HSP 70 antibody (Santacruz, CA)가 1: 1,000으로 PBST 용액에 희석하 여 $4^{\circ} \mathrm{C}$ 에서 overnight 반응시킨 후 PBST용액에서 $10 \mathrm{~min}$ 씩 3 회 동안 세척되었다. 일차 항체에서 반응된 membrane은 donky anti goat, goat anti mouse IgG conjugated secondary antibody가 첨가된 용액에서 1 시간 동안 반응된 다음 PBST용 액에서 $10 \mathrm{~min}$ 씩 3 회 동안 세척되었다. 세척된membranes은 ECL detection reagent (Amersham, USA) 용액 $(1 \mathrm{ml})$ 에 1분 간 노출된 후 imaging system인 Bio-Rad chemidoc XRS을 통 해 immuno reactive bands의 상대적 강도가 정량화되었다.

\section{자료처리}

자료는 SPSS Ver 18.0 통계 package를 이용하여, 각 변인들 간에 평균 및 표준편차를 산출한 후 집단간 one-way ANOVA 를 실시하였고, 사후검증은 Duncan방법을 이용하였으며, 유 의수준은 $a=0.05$ 로 설정하였다.

\section{결과 및 고찰}

\section{고강도 운동이 TBARS 농도에 미치는 영향}

4 주간의 유산소운동과 흑마늘 섭취 후 고강도 운동을 실시 하였을 때 TBARS 농도는 Table 2와 같다. 흑마늘운동군은 흑
Table 2. Changes in TBARS

\begin{tabular}{|c|c|}
\hline Group variable & TBARS $(\mathrm{nmol} / \mathrm{ml})$ \\
\hline$A(n=6)$ & $47.6 \pm 3.14^{\mathrm{a}}$ \\
\hline$B(n=6)$ & $43.1 \pm 3.43^{b}$ \\
\hline$C(n=6)$ & $41.5 \pm 2.16^{\mathrm{b}}$ \\
\hline$D(n=6)$ & $36.3 \pm 1.21^{\mathrm{C}}$ \\
\hline
\end{tabular}

Values were $\mathrm{M} \pm \mathrm{SD}$

A: normal group

B: exercise group

C: black garlic intake group

D: black garlic intake with exercise group

$a, b, c$ Data were significantly different analyzed with one-way ANOVA followed by Duncan's multiple range test $(p<0.05)$.

마늘군 $(p<0.05)$, 운동군 $(p<0.05)$ 과 대조군 $(p<0.001)$ 에 비해 유 의하게 낮았고 흑마늘군과 운동군은 대조군( $p<0.05)$ 에 비해 유의하게 낮았다.

지질과산화를 측정하는 방법으로 $\mathrm{MDA}$ 와 TBARS를 측정하 는 방법이 있으며, 지질과산화 산물 중 가장 많이 형성되는 물질로서 $\mathrm{TBA}$ 와 반응시켜 측정하는데, $\mathrm{MDA}$ 는 다른 종류의 과산화 물과도 반응함으로 TBARS로 측정을 하는 것이 더 쉽 게 측정되기 때문에 TBARS량 측정법이 많이 이용된다[36]. 규칙적인 유산소운동은 신체조직에 자연적인 자극을 주어 생리적 기능저하를 지연시켜주고, 항산화 방어체계를 활성화 시켜주어 활성산소에 의한 손상을 감소시켜준다. 그러나 격렬 한 운동은 활성산소의 생성이 높아짐에 따라 세포의 항산화 기전에 커다란 변화가 생길 수 있으며, 생체 내 세포막의 손상 을 유발시키고, 고 불포화 지방산과 반응해서 지질과산화를 촉진시킨다[17].

지질과산화는 운동강도와 운동기간에 따라 다른데, 저강도 와 중강도 사이의 운동강도에서는 지질과산화가 감소하나, 고 강도에서는 증가한다고 하였다[8,21]. 그러나 흰쥐를 대상으로 탈진적 운동을 실시하였지만 플라보노이드와 폴리페놀을 많 이 함유된 부추를 섭취시켰을 때 대조군보다 지질과산화가 유의하게 낮았고[23], 마늘섭취군이 탈진운동군 보다 유의하 게 낮아[24] 항산화제 식품이 항산화 효소의 활성을 높여 지질 과산화를 감소시켰다고 하였다.

본 연구에서 고강도의 탈진적 운동을 실시하였지만 규칙적 인 운동과 흑마늘 투여를 통해 항산화 방어 체계가 강화되어 지질과산화를 억제한 것으로 사료되고, 운동과 더불어 흑마늘 투여를 병행하였을 때 시너지 효과가 나타나 지질과산화 감소 에 더 효과적인 것으로 나타났다. 따라서 고강도의 탈진운동 이지만 규칙적인 운동과 항산화 식품을 병행한다면 산화적 스트레스를 줄일 수 있을 것으로 사료된다.

고강도 운동이 HSP 70 발현에 미치는 영향

4 주간의 유산소운동과 흑마늘 투여 후 고강도 운동을 실시 


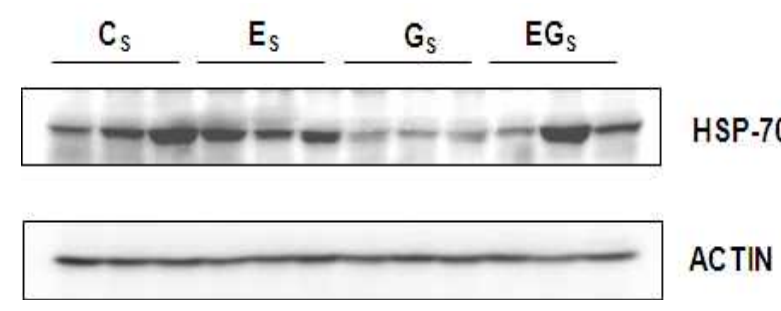

Fig. 1. HSP 70 protein expression in liver. The mice were administered vehicle control $\left(C_{S}\right)$, exercise $\left(E_{S}\right), 2.86$ $\mathrm{mg} / \mathrm{kg}$ black garlic extract (Gs), $2.86 \mathrm{mg} / \mathrm{kg}$ black garlic $\mathrm{s}$ extract with exercise (EGs) for 4 weeks. The liver tissue was lysed and then equal amounts of proteins $(30 \mu \mathrm{g})$ were separated on SDS-polyacrylamide gels and transferred to nitrocellulose membranes. Membranes were probed with the indicated antibodies. An ECL detection system was used for visualization of proteins. Actin was used as an internal control.

하였을 때 HSP 70 발현은 Fig. 1과 같다. 대조군, 운동군과 흑마늘운동군에서 HSP 70 의 발현이 높게 나왔으나 흑마늘섭 취군은 다른군에 비해 상대적으로 낮게 나타났다.

운동으로 인한 세포 내 손상 및 근육조직 내 단백질 발현은 운동 강도와 시간 및 운동 형태와 관련이 있는 것으로 잘 알려 져 있다. 또한 환경변화에 따른 일회성 고강도 운동이 체온증 가와 산화적 스트레스로 인한 골격근 세포의 다양한 스트레스 환경을 유발시켜 세포 내 정상 단백질의 구조를 변화시키고 기능적으로 불활성화 시키는데, 이때 발현되는 HSPs은 세포 의 정상적인 기능 유지에 중요한 단백질과 결합하여 구조를 조절하고 활성화 상태를 유지시킨다[19,31].

운동과 관련하여 조직에서 HSP 증가와 mechanism은 아직 명확하게 밝혀지지 않았지만, 운동이 HSP 발현을 유도하는 가능한 mechanism은 조직의 온도 상승, 산화스트레스, 글루 코스의 고갈, 글리코겐의 저장량의 변화, hypoxia, ischemia, 세포액의 칼슘 수준 증가, $\mathrm{pH}$ 의 감소 등이 있으며 운동이 이러 한 요소가 2개 이상 복합적으로 작용하여 나타난다고 보고하 고 있다[18,25]. 또한 운동수행 중 활성산소를 생성하는 산화적 대사로 인한 산화스트레스에 보다 많이 노출되기 때문에 HSP 70가 높게 발현된다고 하였다[30,32].

마늘은 알리신을 많이 함유하고 있어서 선행연구에서 이러 한 물질을 섭취하게 되면 TBARS와 MDA (malondialdehyde) 와 같은 지질과산화물을 억제시키고, 산화스트레스를 줄일 수 있는 SOD, CAT, GPx 등 항산화 효소가 활성화 된다고 하였다 [7]. 또한 마늘은 식이섬유와 폴리페놀 성분이 풍부하여 활성 산소종을 제거하고, 흡연자에게 숙성된 마늘을 14 일간 섭취시 켰을 때 산화적 스트레스를 감소시킨다고 하였다[6].

본 연구에서는 규칙적인 운동으로 인하여 산화적 스트레스 에 대한 내성이 강화되어 HSP 70의 발현이 감소할 것으로 생 각하였으나 탈진적 운동으로 고온(heat shock)과 고강도의 운

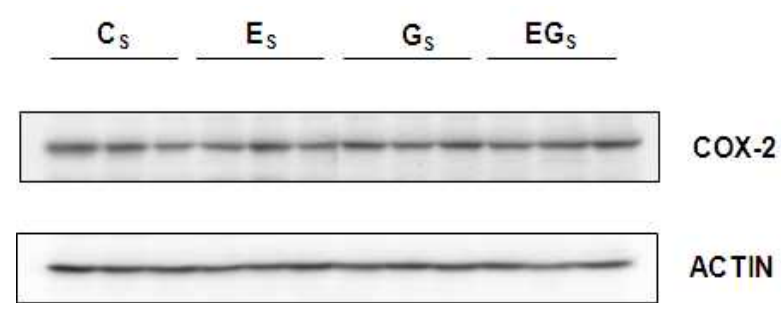

Fig. 2. COX-2 protein expression in liver. The mice were administered vehicle control $\left(C_{S}\right)$, exercise $\left(E_{S}\right), 2.86$ $\mathrm{g} / \mathrm{kg}$ black garlic extract (Gs), $2.86 \mathrm{mg} / \mathrm{kg}$ black garlic extract with exercise (EGs) for 4 weeks. The liver tissue was lysed and then equal amounts of proteins $(30 \mu \mathrm{g})$ were separated on SDS-polyacrylamide gels and transferred to nitrocellulose membranes. Membranes were probed with the indicated antibodies. An ECL detection system was used for visualization of proteins. Actin was used as an internal control.

동으로 두 가지 스트레스요인이 동시에 작용하여 조직의 손상 을 많이 가져왔기 때문에 효과가 나타나지 않은 것으로 사료 된다. 그러나 흑 마늘의 섭취는 HSP 70의 발현이 낮게 나타나 마늘의 주성분인 알리신이나 폴리페놀 등과 같은 성분들이 산화적 스트레스를 감소시켜 HSP 70의 발현이 낮게 나타난 것으로 사료된다.

고강도의 탈진적인 운동으로 인해 HSP 70의 증가는 세포가 받는 스트레스를 감소시키는 중요한 역할을 하지만 항산화 보조식품을 섭취함으로써 스트레스를 방어할 수 있는 기능이 향상될 수 있을 것으로 사료되어 지며, 향후 운동방법 및 항산 화 식품과 관련하여 더 많은 연구를 통해 산화적 스트레스를 줄일 수 있는 방법에 대해 추가적인 연구가 필요할 것으로 사료된다.

\section{고강도 운동이 COX-2 발현에 미치는 영향}

4 주간의 유산소운동과 흑마늘 투여 후 고강도 운동을 실시 하였을 때 COX-2 발현은 Fig. 2와 같으며 모든 군에서 비슷한 발현을 보이고 있다.

COX-2는 COX-1과는 달리 정상상태에서는 발현되지 않으 나, 염증세포나 면역세포에서 인터페론, 사이토카인, 성장인 자 등과 같은 물질 등에 의해 발현이 증가 되어진다[34].

선행연구에서 규칙적인 운동과 폴리페놀성분인 quercetin 투여가 염증성 사이토카인이나 염증 유발 인자를 억제함으로 서[1,9], 심혈관계 질환의 이환율 및 사망률을 증가시키는 COX-2의 발현을 억제하는데 유용한 효과가 있는 것을 확인할 수 있다고 했으며, 정상 및 당뇨병 백서의 신장에서 COX-2의 $\mathrm{mRNA}$ 및 단백질 발현을 살펴본 결과 정상집단에 비해 당뇨 병 집단의 신장에서 COX-2의 발현이 증가하는 것을 확인할 수 있었다[16]. 또한 스트렙토조토신 유발 당뇨쥐가 정상쥐에 비해 신장 피질에서 COX-2 발현이 증가하였다고 보고하여 
[20] 당뇨병 시 고혈압 동반 및 혈관 기능 장애를 예상 할 수 있다.

그러나 본 연구에서는 COX-2의 발현이 집단간 차이를 보이 지 않았는데, 이는 고강도의 탈진적 운동으로 인해 산화적 스 트레스가 증가하였지만 규칙적인 운동과 흑마늘의 투여로 인 하여 염증성 사이토카인의 증가가 없는 것으로 생각되며, 또 한 정상쥐로 실험을 하여 염증 유발인자가 증가하지 않아 $\mathrm{COX}-2$ 의 발현에 차이가 없는 것으로 사료된다.

그러나 선행연구에서 유산소성 운동은 COX-2를 억제시키 는 것으로 나타나[10,26], 운동방법과 관련하여 다양한 연구와 정상쥐가 아닌 당뇨병이나 고혈압을 가진 쥐를 대상으로 실험 을 한다면 COX-2에 대한 단백질 발현과 염증성 인자에 대한 관계를 더욱더 구명할 수 있을 것으로 사료된다.

\section{References}

1. Abramson, J. L. and Vaccarino, V. 2002. Relationship between physical activity and inflammation among apparently healthy middle aged and older adults. Arch Int. Med 162, 1286-1292.

2. Bae, G. W. 2009. Effects of black garlic intake on exhaust variables in blood, immunoglobulin, liver function and antioxidants after the maximal exercise. Ph. D. Dissertation. Keimyung University.

3. Ban, H. N. 2010. The Effects of Circuit Training and Black Garlic Intake on Health Related Fitness, Lipid Profiles, C-Reactive Protein and Bone Density in Middle-aged Women. MS Thesis. Pusan National University.

4. Bedford, T. G., Tipton, C. M., Wilson, N. C., Oppliger, R. A. and Gisolfi, C. V. 1979. Maximum oxygen consumption of rats and its changes with various experimental procedures. J. Appl. Physiol. 47, 1278-1283.

5. Burgio, M. R., Kim, C. J., Dow, C. C. and Koretz, J. F. 2000. Correlation between the Chaperone-like Activity and Aggregate Size of a-Crestallin With Increasing Temperature. Biochem Biophys. Res. Commun. 268, 426-432.

6. Dillson, S. A., Lowe, G. M., Billington, D. and Rahman, K. 2002. Dietary supplementation with aged garlic extract reduces plasma and urine concentrations of 8-iso-protaglandin $\mathrm{F}(2$ alpha) in smoking and nonsmoking men and women. J. Nutr. 132, 163-170.

7. Duda, G., Suliburska, J. and Pupek-Musialik, D. 2008. Effects of shorts-term garlic supplementation on lipid metabolism and antioxidant status in hypertensive adults. Pharmacol. Rep. 60, 163-170.

8. Eom, W. S. 2004. The effect of 12 weeks aerobic exercise with different exercise intensity on lipid peroxidation (MDA) and antioxidant enzyme (SOD). Exer. Sci. 13, 335-350.

9. Ferrucci, L., Cherubini, A., Bandinelli, S., Bartali, B., Corsi, A. and Lauretani. B. 2006. Relationship of plasma polyunsaturated fatty acids to circulating inflammatory markers.
J. Clin. Endocrinol. Meta. 91, 436-446.

10. Geffken, D. F., Cushman, M., Benett, M., Burke, G. L., Polak, J. F., Sakkinen, P. A. and Tracy, R. P. 2001. Association between physical activity and markers of inflammation in a healthy elderly population. Am J. Epidemiol. 183-187.

11. Hart, F. U. and Hayer-Hartl, M. 2002. Molecular chape rones in the cytosol: from nascent chain to folded protein. Science $295,1852-1858$

12. Huang, M., Stolina, M., Sharma, S., Mao, J. T., Zhu, L. P., Miller, W., Wollman, J., Herschman, H. and Dubinett, S. M. 1998. Non-small cell lung cancer cyclooxygenase-2-dependent regulation of cytokine balance in lymphocytes and macrophage Up-regulation of interleukin 10 and down-regulation of interleukin 12 production. Cancer Res. 58, 1208-1216.

13. Jenkins, R. R. 1993. Exercise, oxidative stress and antioxidants: a review. Int. J. Sports Nutr. 3, 356-375.

14. Jun, J. K., Yoon, A. R., Lee. K. M. and Lee, W. L. 2006. The effect of acute exhaustive exercise and long-term endurance exercise training on the protein expression of Mn-SOD, HSP70 and PPAR-y in the heart of rats. Kor. J. Exer. Nutr. 13, 161-167.

15. Kevin, C. K. 2002. Heat shock proteins: modifying factors in physiological stress responses and acquired thermotolerance, J. Appl. Physiol. 92, 2177-2186.

16. Kim, H. T. 2005. The expression of regular exercise on COX-2 mRNA and protein in the diabetic rats renal. Kor. J. Phy. Edu. 44, 381-390.

17. Kimura, N., Satoshi, T., Iuchi, Y., Abe, H., Totsukawa, K. and Fujii, J. 2010. Intrinsic oxidative stress causes either two-cell arrest or cell death depending on developmental stage of the embryos from SOD1-deficient mice. Mol. Hum Reprod 16, 441-451.

18. Knowlton, A. 2000. An overview of the heat shock proteins, their regulation, and function. In: Heat Shock Proteins and the Cardiovascular System, A. Knowlton (Ed). Boston: Kluwer Academic Publishers, 1-24.

19. Koh, T. J. and Escobedo, J. 2004. Cytoskeletal disruption and small heat shock protein translocation immediately after lengthening contractions. Am J. Physiol. Cell Physiol. 286, c713-c722.

20. Komers, R., Lindsley, J. N., Oyama, T. T., Schutzer, W. E., Reed, J. F. and Mader, S. L. 2001. Immunohistochemical and functional correlations of renal cyclooxygenase-2 in experimental diabetes. J. Clin. Invest. 107, 889-898.

21. Krihnan, R. K., Evans, W. J. and Kirwan, J. P. 2003. Impaired substrate oxidation in healthy elderly men after eccentric exercise. J. Appl. Physiol. 94, 716-723.

22. Lee, G. P. and Lim, I. S. 2000. The changes of MDA, SOD, and catalase by overtraining. Kor. J. Phy. Edu. 39, 426-435.

23. Lee, S. H, and Baek, Y. H. 2011. The effect of leeki during exhaustive exercise on lipid metabolism and antioxidant enzyme activities in Rats. Kor. J. Sports Sci. 20, 1439-1450.

24. Lee, H. M., Seo, D. Y., Lee, S. H. and Baek, Y. H. 2010. Effects of exhaustive exercise and aged garlic extract supplementation on weight, adipose tissue mass, lipid profiles and 
oxidative stress in high fat diet induced obese rats. J. Life Sci. 20, 1889-1895.

25. Locke, M. and Tanguay, R. M. 1996. Increased HSP activation in muscles with a high constitutive HSP70 expression. Cell Stress Chaperones 1, 189-196.

26. Monzillio, L. U. and Christos, S. 2003. Effect of lifestyle modification on adipokine levels in obese subjects with insulin resistance. Obese Res. 11, 1048-1054.

27. Moreno F. J., Corzo - Martinez, M., Castillo, M. D. and Villamiel, M. 2006. Change in antioxidant activity of dehydrated onion and garlic during storage. Food Research International 39, 185-192.

28. Morimoto R. I. 1993. Cell in stress: Transcriptional activation of heat shock genes. Science 259, 1409-1410.

29. Naoaki, M., Mitsuyasu, U., Naoki, K., Takeshi, N., Minoru, H. and Hidekatsu, T. 2006. Aged garlic extract ameliorates physical fatigue. Biol. Pharm Bull. 29, 962-966

30. Oishi, Y., Taniguchi, K., Matsumoto, H., Ishihara, A., Ohira, Y. and Roy, R. R. 2002. Muscle type-specific response of HSP60, HSP72, and HSC73 during recovery after elevation of muscle temperature. J. Appl. Physiol. 92, 1097-1103.

31. Paulsen, P. G., Vissing, K., Kalhovde, J. M., Ugelstad, I., Bayer, M. L., Kadi, F., Schjerling, P., Hallen, J. and Raastad, T. 2007. Maximal eccentric exercise induces a rapid accumulation of small heat shock proteins on myofibrils and a delayed HSP70 response in humans. Am J. Physiol. 293, 844-853.

32. Powers, S. K., Ji, L. L. and Leeuwenburgh, C. 1999. Exercise training-induced alterations in skeletal muscle antioxidant capacity: a brief review. Med Sci. Sports Exer. 31, 987-997.

33. Reddy, G. B., Das, K. P., Petrash, J. M. and Surewicz, W. K. 2000. Temperature -dependent chaperone activity and structural properties of human aA-and aB-crystallins. J. Biol. Chem 18, 4565-4570.

34. Sato, T., Nakajima, H., Fujio, K. and Mori, Y. 1997.
Enhancement of prostaglandin E2 production by epidermal growth factor requires the coordinate activation of cytosolic phospholipase A2 and cyclooxygenase 2 in human squamous carcinoma A431 cells. Prostaglandins 53, 355-369.

35. Schwartz, I. F., Hershkovitz, R., Iaina, A., Gnessin, E., Wollman, Y., Chenichowski, T., Blum, M., Levo, Y. and Schwartz, D. 2002. Garlic attenuates nitric oxide production in rat cardiac myocytes thought inhibition of inducible nitric oxide synthase and arginine transporter CAT-2 (cationic amino acid transporter-2). Clin. Sci. 102, 487-493.

36. Seo, Y. H. 2004. Effects of TaeKwonDo training on blood antioxidant enzymes and lipid peroxidation. Chosun University.

37. Seong, N. J. 2008. Physicochemical composition and antioxidant activity of black garlic. Food Preserv. Proc. Industry 7, 45-53.

38. Smolka, M. B., Zoppi, C. C., Alves, A. A., Silveira, L. R., Marangoni, S., Pereira-Da-Silva, L., Novello, J. C. and Nacedo, D. V. 2000. HSP72 as a complementary protection against oxidative stress induced by exercise in the soleus muscle of rats. Am J. Physiol. Regul. Integr. Comp Physiol. 279, R1539-R1545.

39. Thompson, C. E., Thompson, T. R., Alers, J. J. and Decedue, C. J. 1985. Response of HDL cholesterol, apoprotein A-I, and LCAT to exercise withdrawal. Atherosclerosis 54, 65-73.

40. Vane, J. R., Bakhle, Y. S. and Botting, R. M. 1998. Cyclooxygenase 1 and 2. Amu. Rev. Pharmacol. Toxicol. 38, 97-120.

41. Vigue, C. A. L. P., Ames, B. N. and Brooks, G. A. 1993. Oxidant stress in human blood during exercise. Appl. Physiol. 75, 566-572.

42. Welch, W. J. 1993. Heat shock proteins functioning as molecular chaperones: their roles in normal and stressed cells. Philos. Trans. R. Soc. Lond B. Biol. Sci. 339, 327-333.

\section{초록 : 흑마늘 투여와 운동이 고강도 운동 후 TBARS, HSP 70 및 COX-2 발현에 미치는 영향}

백영호 ${ }^{1} \cdot$ 이상호 ${ }^{1} \cdot$ 한민호 $^{2} \cdot$ 최영현 ${ }^{2,3} \cdot$ 김승현 $^{1} \cdot$ 곽이섭 $^{4}{ }^{*}$

$\left({ }^{1}\right.$ 부산대학교 체육교육과, ${ }^{2}$ 동의대학교 대학원 바이오물질제어학과, ${ }^{3}$ 동의대학교 한의과대학 생화학교실, ${ }^{4}$ 동의대학교 체육학과)

실험동물은 생후 4 주령 Sprague Dawley계 수컷 흰쥐 24마리로 흑마늘운동군(6마리), 운동군(6마리), 흑마늘군 (6마리), 대조군(6마리)으로 총 24 마리로 구분하여 운동은 총 4 주간 트레드밀로 실시하였으며, 시료 채취 하기 바 로 직전에 고강도 운동을 실시하였다. 흑마늘 섭취는 흑마늘진액을 구강 투여시켰으며, 연구결과 다음과 같다. 4 주간의 흑마늘 투여와 유산소운동 후 고강도 운동을 실시하였을 때 TBARS 농도는 흑마늘운동군이 흑마늘군, 운동군과 대조군에 비해 유의하게 낮았다. 흑마늘군과 운동군은 대조군에 비해 유의하게 낮았다. HSP 70 발현은 흑마늘섭취군이 다른군에 비해 상대적으로 낮게 나타났다. COX-2 발현은 모든군에서 비슷한 발현을 보이고 있으 며 규칙적인 운동과 흑마늘 섭취는 산화적 스트레스를 줄일 수 있을 것으로 기대된다. 